\title{
Constitution and Validation of a New Symptom Assessment Tool for Overactive Bladder: Marmara Overactive Bladder Questionnaire (M-OBQ)
}

\author{
Marmara Aşırı Aktif Mesane (M-AAM) Sorgulama Formunun \\ Oluşturulması: Geçerlilik ve Güvenilirlik Analizi
}

\author{
Tufan Tarcan, Naşide Mangır, Mehmet Özay Özgür, Abdülkadir Gümrah, Cem Akbal \\ Marmara University Faculty of Medicine, Department of Urology, Istanbul, Turkey
}

\begin{abstract}
What's known on the subject? and What does the study add?
The linguistically validated Turkish version of OAB- V8 questionnaire that involves the first 8 questions of the original $0 A B$ form is being used since 2006 in our country. The reliability analysis of this form was performed by our group recently. Although the currently used Turkish version of $0 A B-V 8$ questionnaire is the best available symptom assessment tool to be used in patients with $O A B$, it does not allow us to question the quality of life and sexual effects of the disease.
\end{abstract}

\section{ABSTRACT}

Objective

The aim of this study is to constitute and validate a symptom questionnaire to be used in the diagnosis and follow up of patients with OAB that complies with the specific needs of the Turkish society and that allows the assessment of both disease symptoms and their effects on quality of life.

\section{Materials and Methods}

A total of $78 \mathrm{OAB}$ patients and 90 control patients were included in this study between January 2007 and June 2007. All included patients underwent urine analysis/culture, blood creatinine levels, 3-day voiding dairy, urinary ultrasonography and plain abdominal graphy evaluations.

Results

Among 168 patients included $99(58,95)$ were males and $69(41,1 \%)$ were females. Mean age was $47,3( \pm 17,2)$ years. Cronbach alpha value which is a determinant of internal consistency was 0.92 for $\mathrm{M}-\mathrm{OAB}$ questionnaire. The Spearman correlation co- efficient for total score was found to be 0.98 $(p=0.001)$ in the test- retest analysis. The highest sensitivity $(97 \%)$ and specificity (94\%) values for the M-OAB questionnaire to make a diagnosis of $O A B$ were obtained with a cut off value of 12.5 for the total score.

Conclusion

This study shows the development of a reliable and valid $O A B$ specific symptom and quality of assessment tool that is short and easily applicable in the daily clinical practice. This questionnaire can provide the clinicians with practical comfort and a standardized quantification of the patient symptoms. Key Words

Overactive bladder, symptom questionnaire, validation, quality of life

\section{ÖZET}

Amaç

Aşırı aktif mesane (AAM) hastalarının tanı ve izlemlerinde kullanılabilecek, hastalığın semptomlarını ve hayat kalitesi üzerine etkilerini aynı anda sorgulayabilen, Türk toplumunun kendi özelliklerine uygun bir sorgulama formunun oluşturulması amaçlanmıştır.

Gereç ve Yöntem

Ocak 2007-Haziran 2007 tarihleri arasında AAM tanısı ile takip edilen 78 hasta ve şikayeti olmayan 90 hasta çalıșmaya dahil edildi. Calışmaya dahil edilen hastaların her birinin idrar tahlili/kültürü, kan kreatinin ölçümü, 3 günlük işeme günlüğü, üriner sistem ultrasonografisi ve direkt üriner sistem grafisi incelemeleri yapılmıştır.

Bulgular

Çalışmaya dahil edilen 168 hastanın 99'u $(\% 58,9)$ erkek ve 69'u $(\% 41,1)$ kadındı ve yaş ortalamaları 47,3 $( \pm 17,2)$ olarak bulundu. M-AAM sorgulama formunun iç tutarlılığının bir ölçüsü olan Cronbach alfa değeri 0,92 olarak hesaplandı. Test-Tekrar test tutarlılığı hesaplandığında toplam skor için Spearman korelasyon katsayısı $r=0,98 \quad(p=0,001)$ olarak bulundu. Kesme değeri 12,5 olarak alındığında M-AAM'nin AAM tanısı koymadaki en yüksek sensitivite ve spesifisite değerleri elde edilmektedir, sırasıyla \%97ve \%94'tür. Sonuç

Ülkemizde AAM hastalığına özgü kısa ve kolay uygulanabilen, semptom ve hayat kalitesi sorgulaması yapabilen geçerli ve güvenilir bir sorgulama formu geliştirilmiştir. Bu sorgulama formu hem klinik pratikte kolaylık hem de bilimsel çalışmalarımızda standardizasyon sağlayacaktır. Aynı formun gelecekte yabancı dillerde validasyonunun gerçekleştirilmesi ile uluslararası kullanımı da mümkün olabilecektir.

Anahtar Kelimeler

Aşırı aktif mesane, sorgulama formu, vallidasyon, yaşam kalitesi

\section{Correspondence}

Naşide Mangır MD, Marmara University Facult of Medicine, Urology, İstanbul, Turkey

E-mail:info@tufantarcan.com

Journal of Urological Surgery. 


\section{Introduction}

Overactive Bladder (OAB) was first described by Abrams et al. in 1997 (1) and in 2002 it was defined by International Continence Society (ICS) as "urgency, with or without urge incontinence, usually with frequency and nocturia, in the absence of pathologic or metabolic conditions that might explain these symptoms" (2). OAB is a chronic disease with a prevalence of $12.4-53.1 \%(3,4,5)$ and it is associated with decreased quality of life and high health care costs (6).

In clinical practice the diagnosis of $O A B$ is a clinical diagnosis that involves elimination of other causes and relies mainly on the symptoms of patients instead of objective findings such as urodynamic diagnosis. This necessitates the use of patient reported outcome measurement tools such as symptom questionnaires in diagnosis and management of $O A B$ syndrome (7). A variety of questionnaires has been devised for use in patients with urinary incontinence (8) but the only symptom questionnaire specific for $O A B$ is $O A B-q$ questionnaire that was constituted in English language in 2002 (9).

The linguistically validated Turkish version of $O A B-V 8$ questionnaire that involves the first 8 questions of the original $O A B$ form is being used since 2006 in our country (10). The reliability analysis of this form was also performed by our group recently (11). Although the currently used Turkish version of OAB-V8 questionnaire is the best available symptom assessment tool to be used in patients with $O A B$, it does not allow us to question the quality of life and sexual effects of the disease. Also our experiences with the use of this form during daily clinical practice in our clinic has suggested that it could be possible to further modify this form to meet the specific needs of our society. For example we have changed the expression "frequent voiding during daytime" as "going to toilet more than 8 times during daytime" or similarly "a disturbing sense of urgency", "a sudden/ unexpected sense of urgency" and "an uncontrollable desire to void" was questioned with a single question in our form as "going to toilet with a sudden sense of urgency". Likewise we have asked the original "nocturia" and "waking up during night to go to urinate" in a single question "waking up with a sense to urinate and going to toilet" in our form.

The aim of this study is to constitute and validate a symptom questionnaire to be used in the diagnosis and follow up of patients with $O A B$ that complies with the specific needs of the Turkish society and that allows the assessment of both disease symptoms and their effects on quality of life.

\section{Materials and Methods}

\section{Constitution of Marmara Overactive Bladder (M-OAB) Questionnaire}

All the existing questionnaires for $O A B$, urinary incontinence and pelvic floor diseases were reviewed. The need for a specific questionnaire that can be used to improve the diagnosis, symptom and quality of life effects evaluation of $O A B$ was established. A set of questions from our clinical experiences were listed and these were simplified after one- to one interviews with patients and target group studies. During these procedures the specific phrases and concepts that are better perceived and most comfortably used by the patients were determined. As a result 8 questions that inquire about the symptoms of $O A B$ and their effects on quality of life were established. An analog scale that allows the patient to grade the severity of his/ her urgency which is the most important symptom of $O A B$, was included at the end of the questionnaire. The validation studies of the constituted M- OAB questionnaire was initiated afterwards.

\section{The Validation Studies of Marmara Overactive Bladder (M-OAB) Questionnaire}

A total of $78 \mathrm{OAB}$ patients and 90 control patients were included in this study between January 2007 and June 2007. All included patients underwent urine analysis/ culture, blood creatinine levels, 3- day voiding dairy, urinary ultrasonography and plain abdominal graphy evaluations. The diagnosis of $O A B$ was a clinical diagnosis based on history, urine flow- chart, laboratory and radiological findings.

Patients completed the M-OAB questionnaire 2 times with 2 weeks interval between the evaluations. The questionnaire consisted of 8 questions each of which evaluated the symptom severity graded by the patients as not at all (0), Mild (1), moderate (2), severe (3) and extremely severe (4) and an analog scale that allows grading the severity of the symptom "urgency". Total score ranged between a minimum of $0+0$ and a maximum of $32+10$.

The analysis of validation was performed using SPSS v15.0 software. Internal consistency was evaluated by Cronbach alpha value and testretest analysis. The cut off value was calculated by the ROC analysis.

\section{Results}

Among 168 patients included $99(58,95)$ were males and $69(41.1 \%)$ were females. The mean age was $47.3( \pm 17.2)$ years.

The mean $M-O A B$ scores of $O A B$ and control patients are shown in Table 1. The mean M-OAB scores of OAB patients and control patients were $19.5 \pm 6.2$ and $4.1 \pm 3.2$, respectively $(p=0.001)$. The $O A B$ patients included in the study were wet OAB in $30.8 \%(n=24)$ and dry OAB in $69.2 \%(n=54)$.

The Cronbach alpha value which is a determinant of internal consistency was 0.92 for M-OAB questionnaire (Table 2). This value was higher than the recommended value of 0.7 . The correlation of each question with the other questions were shown in Table 3.

Among all questions and the analog scale the strongest correlation with the total score was observed for the questions 5, 6 and 7 (Table 2).

The Spearman correlation co- efficient for total score was found to be $0.98(p=0.001)$ in the test- retest analysis (Figure 1). When the questions were evaluated individually the ones with the highest consistency were questions $1(r=0.96), 3(r=0.95), 5(r=0.95)$ and 6 $(r=0.95)$. The question that has the lowest test- retest consistency was the question 8 with a Spearman rho value of 0.83 .

The ROC analysis used to determine the cut off value of the total $M-O A B$ score that would give the highest sensitivity and specificity values is shown in Table 4. The ROC curve used to calculate the cut-off point is shown in Figure 2. The highest sensitivity (97\%) and specificity $(94 \%)$ values for the $M-O A B$ questionnaire to make a diagnosis of $O A B$ were obtained with a cut off value of 12.5 for the total score (Table 4 ).

\begin{tabular}{|c|c|c|c|}
\hline & $\begin{array}{l}\text { Patients with } O A B \\
(n=78)\end{array}$ & $\begin{array}{l}\text { Patients without } \\
O A B(n=90)\end{array}$ & $p$ value \\
\hline M-OAB score & $19.5 \pm 6.2$ & $4.2 \pm 3.2$ & 0.001 \\
\hline Analog Scale & $6.9 \pm 2.5$ & $2.1 \pm 1.5$ & 0.001 \\
\hline
\end{tabular}


The correlation between the analog scale and the total score of the first 8 questions was found be high with a Spearman rho correlation coefficient of $0.79(p=0.001)$ (Figure 3).

\section{Discussion}

M-OAB symptom questionnaire is developed both as a symptom and a basic quality of life assessment questionnaire. It can be deduced that our questionnaire consists of 3 parts: first 4 questions mentioning disease symptoms, last 4 questions measuring quality of life and the analog scale that grades the severity of urgency which is the main symptom of OAB (Figure 4).

Compared to $\mathrm{OAB}-\mathrm{V} 8$ the newly presented $\mathrm{M}-\mathrm{OAB}$ questionnaire provides the clinicians with 3 main advantages: 1) It allows the assessment of quality of life, 2) With use of the analog scale, it allows precise evaluation of how exactly the urgency is experienced by the patient 3) It allows basic evaluation of effects of OAB on sexual functions of the patient. In addition to these, based on our initial experiences related to the use of the questionnaire we observed that this form can be better perceived by Turkish population compared to the OAB-V8 form although there are not any studies on direct comparisons of the two forms. The main restriction of using M-OAB questionnaire can be that it will not be able to allow standardization in the literature initially. For this reason we suggest that it will be plausible to use both $\mathrm{M}-\mathrm{OAB}$ and the validated Turkish version of $\mathrm{OAB}$ $V 8$ until the $M-O A B$ questionnaire gains more widespread acceptance.

Table 2. The corrected correlations of each item in the Marmara Overactive Bladder questionnaire with the total score and the Cronbach alpha values when that question is eliminated

\begin{tabular}{|l|l|l|}
\hline$n=168$ & $\begin{array}{l}\text { Corrected Question- } \\
\text { Total score correlation }\end{array}$ & $\begin{array}{l}\text { The Cronbach alpha value } \\
\text { when the question is } \\
\text { eliminated }\end{array}$ \\
\hline Question 1 & .725 & .906 \\
\hline Question 2 & .657 & .911 \\
\hline Question 3 & .784 & .904 \\
\hline Question 4 & .663 & .911 \\
\hline Question 5 & .876 & .897 \\
\hline Question 6 & .837 & .901 \\
\hline Question 7 & .858 & .898 \\
\hline Question 8 & .572 & .915 \\
\hline Analog Scale & .821 & .923 \\
\hline
\end{tabular}

$\mathrm{M}-\mathrm{OAB}$ questionnaire demonstrates perfect internal consistency and reliability. Also as another parameter in measurement of validity, the test-retest correlation was also found to be very high. This feature of the M-OAB questionnaire suggests that it can also be a reliable assessment tool to be used particularly in the clinical follow up of $\mathrm{OAB}$ patients.

In this study the correlation of M-OAB total score and the analog scale was found to be very high (Spearman rho: 0.79). Considering that the main symptom of $O A B$ is urgency, this correlation is not

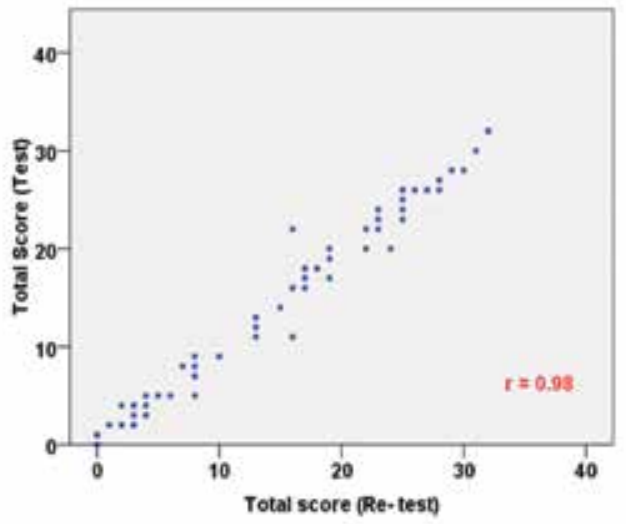

Figure 1 . The Test-Re-test analysis showing the correlation of total score measured 2 times with a 2 week interval (Spearman correlation coefficient $r=0.98)$

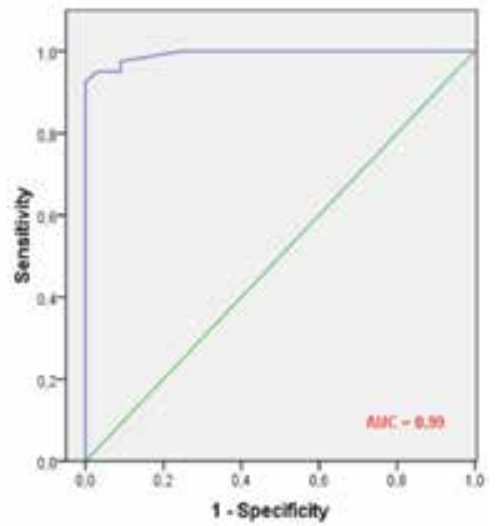

Figure 2. The ROC curve of the Marmara Overactive Bladder (M-OAB) questionnaire (AUC:Area Under Curve=0.99)

Table 3. The correlation of each question of the Marmara Overactive Bladder (M-OAB) questionnaire with other questions

\begin{tabular}{|l|l|l|l|l|l|l|l|l|l|}
\hline & Question 1 & Question 2 & Question 3 & Question 4 & Question 5 & Question 6 & Question 7 & Question 8 & Analog scale \\
\hline Question 1 & 1.000 & .656 & .646 & .408 & .659 & .589 & .669 & .442 & .649 \\
\hline Question 2 & .656 & 1.000 & .587 & .407 & .602 & .565 & .576 & .370 \\
\hline Question 3 & .646 & .587 & 1.000 & .552 & .697 & .658 & .700 & .408 & .749 \\
\hline Question 4 & .408 & .407 & .552 & 1.000 & .657 & .633 & .634 & .420 & .616 \\
\hline Question 5 & .659 & .602 & .697 & .657 & 1.000 & .849 & .837 & .525 & .770 \\
\hline Question 6 & .589 & .565 & .658 & .633 & .849 & 1.000 & .842 & .582 & .700 \\
\hline Question 7 & .669 & .576 & .700 & .634 & .837 & .842 & 1.000 & .546 & .726 \\
\hline Question 8 & .442 & .370 & .408 & .420 & .525 & .582 & .546 & 1.000 & .511 \\
\hline Analog scale & .649 & .566 & .749 & .616 & .770 & .700 & .726 & .511 & 1.000 \\
\hline
\end{tabular}


Table 4. The cut-off values and the corresponding sensitivity and specificity values obtained from the ROC analysis

\begin{tabular}{|l|l|l|}
\hline Cut-off value & Sensitivity & Specificity \\
\hline 10.5 & $98 \%$ & $84 \%$ \\
\hline 11.5 & $97 \%$ & $90 \%$ \\
\hline 12.5 & $97 \%$ & $94 \%$ \\
\hline 13.5 & $94 \%$ & $96 \%$ \\
\hline
\end{tabular}

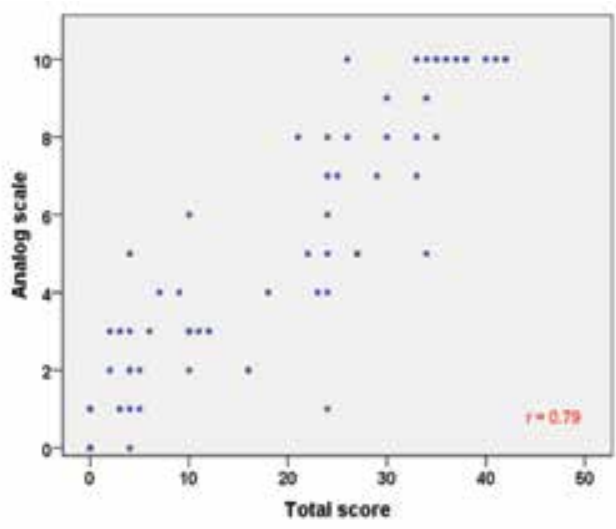

Figure 3. The correlation between Total score and the Analog scale
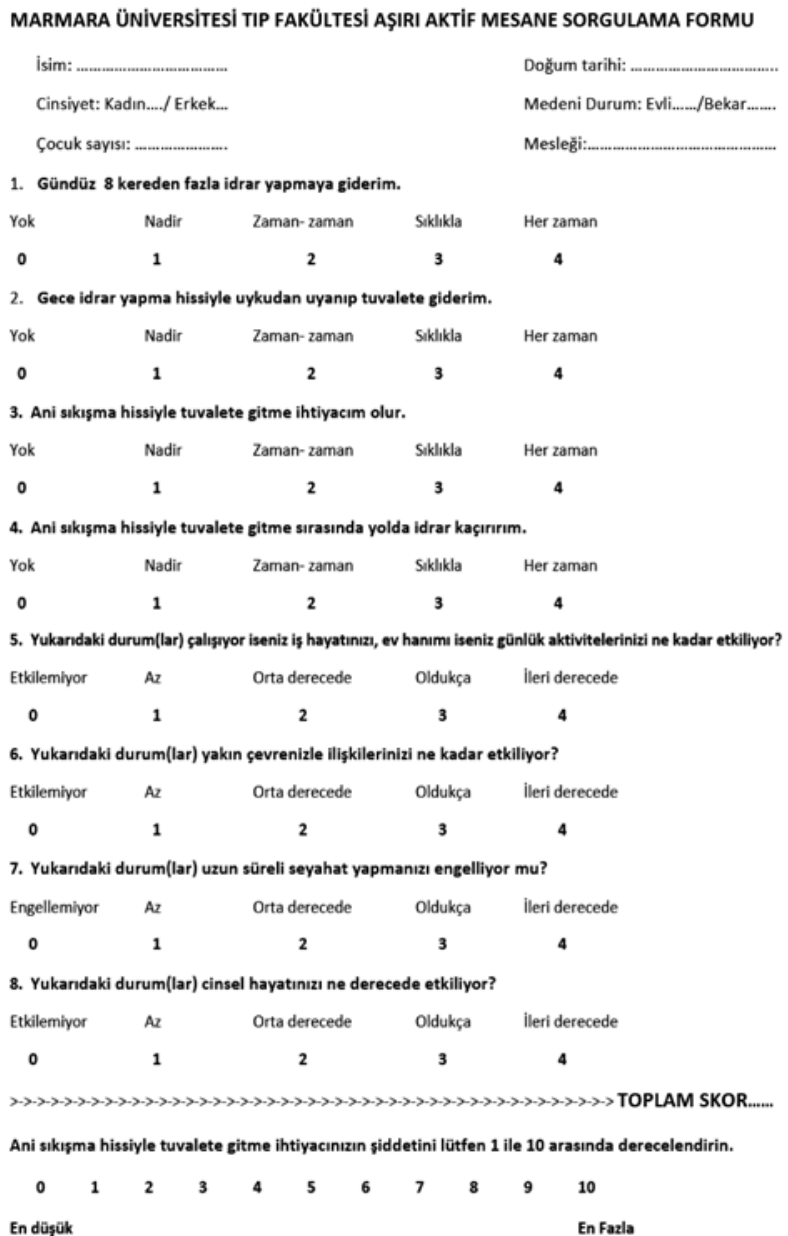

Figure 4. The Marmara Overactive Bladder (M-OAB) questionnaire surprising and also with this correlation evident it can be suggested that analog scale alone can be used as a quick monitorization tool. The lowest consistency in test- retest analysis was evident for question 8 which inquires about sexual health effects of $O A B$ which may be related to the inherent difficulties in assessment of sexual symptoms/ behaviours.

The cut off value we suggest for total score 12. This value as seen in the ROC curve has the highest sensitivity and specificity to distinguish between $\mathrm{OAB}$ and healthy patients.

\section{Conclusion}

This study shows the development of a reliable and valid $O A B$ specific symptom and quality of assessment tool that is short and easily applicable in the daily clinical practice. This questionnaire can provide the clinicians with practical comfort and a standardized quantification of the patient symptoms. It is also presented to the attention of the international scientific community to be considered for further validations in other languages which can allow a more standardized reporting.

\section{References}

1. The Overactive Bladder: From Basic Science to Clinical Management Consensus Conference. Proceedings. London, England, June 29, 1997. Urology 1997;50:1-114.

2. Abrams $P$, Cardozo $L$, Fall $M$, Griffiths $D$, Rosier $P$, Ulmsten $U$, van Kerrebroeck $P$, Victor $A$, Wein A. The standardisation of terminology of lower urinary tract function: report from the Standardisation Subcommittee of the International Continence Society. Am J Obstet Gynecol 2002;187:116-126.

3. Abrams $P$, Kelleher CJ, Kerr LA, Rogers RG. Overactive bladder significantly affects quality of life. Am J Manag Care 2000;6:580-590.

4. Wein AJ, Rovner ES. Definition and epidemiology of overactive bladder. Urology 2002;60:7-12.

5. Homma Y, Yamaguchi 0, Hayashi K. Epidemiologic survey of lower urinary tract symptoms in Japan. Urology 2006;68:560-564.

6. Stewart WF, Van Rooyen JB, Cundiff GW, Abrams P, Herzog AR, Corey R, Hunt TL, Wein AJ. Prevalence and burden of overactive bladder in the United States. World J Urol 2003;20:327-336.

7. Heldwein FL, Sanchez-Salas RE, Sanchez-Salas R, Teloken PE, Teloken C, Castillo 0 , Vallancien $G$. Health and quality of life in urology: issues in general urology and urological oncology. Arch Esp Urol 2009;62:519-530.

8. Matza LS, Thompson CL, Krasnow J, Brewster-Jordan J, Zyczynski T, Coyne KS. Test-retest reliability of four questionnaires for patients with overactive bladder: the overactive bladder questionnaire (OAB-q), patient perception of bladder condition (PPBC), urgency questionnaire (UQ), and the primary OAB symptom questionnaire (POSO). Neurourol Urodyn 2005;24:215-225.

9. Coyne K, Revicki D, Hunt T, Corey R, Stewart W, Bentkover J, Kurth H, Abrams $P$. Psychometric validation of an overactive bladder symptom and health-related quality of life questionnaire: the OAB-q. Qual Life Res 2002;11:563-574.

10. Acquadro C, Kopp Z, Coyne KS, Corcos J, Tubaro A, Choo MS, Oh SJ. Translating overactive bladder questionnaires in 14 languages. Urology 2006;67:536-540.

11. Tarcan T, Mangır N, Özgür MÖ, Akbal C. OAB-V8 Aşırı Aktif Mesane Sorgulama Formu Validasyon Çalışması. Üroloji Bülteni 2012;3 (Article in press). 